DOI: https://doi.org/10.24127/ajpm.v9i3.2917

\title{
KEPRAKTISAN MODEL PEMBELAJARAN IDEA (ISSUE, DISCUSSION, ESTABLISH, AND APLLY) DALAM PEMBELAJARAN MATEMATIKA
}

\author{
Yayan Eryk Setiawan ${ }^{1}$, Mustangin ${ }^{2}$ \\ ${ }^{1,2}$ Pendidikan Matematika/FKIP/Universitas Islam Malang, Malang, Indonesia \\ *Corresponding author. Dusun Krajan 2 RT.03 RW.05 Desa Boreng, 67316, Kabupaten Lumajang, Indonesia \\ E-mail: $\quad \frac{\text { yayaneryksetiawan@unisma.ac.id }}{\text { mustangin@unisma.ac.id }}^{{ }^{2)}}$
}

Received 06 July 2020; Received in revised form 11 September 2020; Accepted 22 September 2020

\begin{abstract}
Abstrak
Salah satu upaya untuk mengatasi kesalahan konsep yang dialami oleh siswa maupun mahasiswa adalah dengan mengembangkan model pembelajaran IDEA (Issue, Discussion, Establish, and Apply) untuk meningkatkan pemahaman konsep. Penelitian sebelumnya menunjukkan bahwa model pembelajaran IDEA ini telah valid secara teoritis. Sebagai penelitian lanjutan, maka perlu diadakan uji coba lapangan dari model pembelajaran IDEA yang telah valid secara teoritis untuk mengetahui kepraktisan model pembelajaran IDEA. Untuk itu, tujuan penelitian ini adalah untuk mengetahui kepraktisan model pembelajaran IDEA dalam pembelajaran Matematika. Metode penelitian ini yaitu penelitian pengembangan. Hasil yang dibahas dalam penelitian ini fokus pada hasil uji coba kelompok kecil dan uji coba kelompok besar yang merupakan bagian dari pengembangan model pembelajaran IDEA. Dari hasil uji coba kelompok kecil diperoleh masukan-masukan yang digunakan untuk merevisi lembar kerja mahasiswa dan menambahkan kegiatan-kegitan pada sintaks model pembelajaran IDEA. Dari hasil uji coba kelompok besar diperoleh tingkat kepraktisan model pembelajaran IDEA adalah tinggi, yaitu sebesar 73,47\% yang berarti bahwa model pembelajaran IDEA praktis untuk dilaksanakan dalam pembelajaran matematika. Selain itu, melalui uji coba kelompok besar diperoleh kelebihan dan kekurangan dari model pembelajaran IDEA. Kelebihan model pembelajaran IDEA yaitu dapat meningkatkan minat belajar, pemahaman konsep, kreativitas, dan membuat suasana belajar menyenangkan. Sedangkan kekurangan model pembelajaran IDEA yaitu membutuhkan waktu yang relatif lama.
\end{abstract}

Kata kunci: Kepraktisan, model pembelajaran IDEA, pemahaman konsep, uji coba model.

\begin{abstract}
One of the efforts to overcome misconceptions experienced by students is by developing an IDEA (Issue, Discussion, Establish, and Apply) learning model to improve conceptual understanding. Previous research has shown that the IDEA learning model is theoretically valid. As follow-up research, it is necessary to hold a field trial of the theoretically valid IDEA learning model to determine the practicality of the IDEA learning model. For this reason, the purpose of this study was to determine the practicality of the IDEA learning model in mathematics learning. This research method is development research. The results discussed in this study focus on the results of small group trials and large group trials that are part of the development of the IDEA learning model. From the results of the small group trial, it was obtained inputs that were used to revise student worksheets and add activities to the syntax of the IDEA learning model. From the results of large group trials, the practicality level of the IDEA learning model was high, namely $73.47 \%$, which means that the IDEA learning model is practical to be implemented in mathematics learning. Also Besides, through large group trials, the advantages, and weakness of the IDEA learning model were obtained. The advantages of the IDEA learning model are that it can increase interest in learning, understanding concepts, creativity, and create a pleasant learning atmosphere. Meanwhile, the weakness of the IDEA learning model is that it takes a relatively long time.
\end{abstract}

Keywords: Concept understanding, IDEA learning model, practicality, trial learning model.

This is an open access article under the Creative Commons Attribution 4.0 International License 
DOI: https://doi.org/10.24127/ajpm.v9i3.2917

\section{PENDAHULUAN}

Salah satu yang ditekankan dalam pembelajaran matematika adalah pemahaman konsep (Setiawan \& Syaifuddin, 2020). Pemahaman konsep didefinisikan sebagai proses atau cara seseorang untuk benar-benar mengetahui atau mengerti tentang ideide yang ada dalam suatu konsep (Setiawan, 2019). Seseorang yang telah memahami suatu konsep akan dapat menjelaskan kembali tentang konsep yang dipelajarinya dengan menggunakan bahasa mereka sendiri dan mereka akan mengetahui cara kerja atau cara memperoleh suatu rumus dalam matematika. Pentingnya pemahaman konsep menyebabkan pemahaman konsep harus diberikan terlebih dahulu sebelum pemahaman prosedural. Karena pemahaman konsep seseorang akan mempengaruhi pemahaman prosedural seseorang, di mana seseorang yang paham terhadap suatu konsep akan mengetahui sistem yang membangun suatu pengetahuan prosedural (Setiawan, 2019).

Berbagai penelitian menunjukkan bahwa masih sering ditemui kesalahan konsep yang dilakukan oleh siswa maupun mahasiswa dalam menyelesaikan masalah matematika (Afifah, Nafi' an, \& Putri, 2018; Afriadi, 2019; Arvianto, 2017; Farhan \& Zulkarnain, 2019; Jana, 2018; Lembang \& Ba'ru, 2018; Lusiana, 2017; Oktaviana, 2018; Rosmaiyadi, 2018; Sembiring, 2017). Hasil penelitian Setiawan dan Mustangin (2020b) menunjukkan bahwa dari 33 mahasiswa yang menyelesaikan soal pemahaman konsep diperoleh $72,27 \%$ mahasiswa masih salah dalam menyatakan kembali konsep sudut yang sudah dipelajari. Hasil penelitian Setiawan (2020b) menunjukkan bahwa dari 24 siswa sekolah menengah atas kelas $\mathrm{X}$ diperoleh: $33 \%$ siswa mengalami kesalahan konsep dalam memahami definisi segitiga sebagai poligon yang memiliki tiga sisi, $67 \%$ siswa mengalami kesalahan konsep dalam memahami definisi akar kuadrat, dan $70 \%$ siswa mengalami kesalahan konsep dalam memahami definisi limas segiempat. Hasil penelitian Setiawan (2020a) menunjukkan bahwa siswa yang belum mampu melakukan pembuktian kesebangunan dua segitiga cenderung menggunakan pemahaman yang salah atau kesalahan pemahaman konsep. Hasil penelitian menunjukkan bahwa siswa yang hanya mendapatkan pembelajaran dengan mengingat, akan lebih mudah lupa terhadap materi yang dipelajari daripada siswa yang benarbenar memahami suatu konsep materi matematika (Setiawan, 2020c). Jadi kesalahan konsep masih dialami oleh siswa maupun mahasiswa dalam belajar matematika.

Kesalahan konsep yang dialami oleh siswa maupun mahasiswa memiliki hubungan dengan pembelajaran yang dilakukan oleh guru maupun dosen di kelas. Kemampuan guru mempengaruhi pembelajaran di kelas yang pada akhirnya mempengaruhi prestasi belajar siswa (Setiawan, 2015). Lebih lanjut Setiawan dan Mustangin (2020a) mengatakan bahwa kesalahan konsep siswa maupun mahasiswa tidak lepas dari pengaruh guru atau dosen dalam melakukan pembelajaran, dimana siswa maupun mahasiswa cenderung meniru cara-cara yang digunakan oleh guru atau dosen (Setiawan, Purwanto, Parta, $\&$ Sisworo, 2020). Hasil penelitian Setiawan (2020b) menunjukkan bahwa faktor yang menyebabkan kesalahan konsep adalah tidak mendapatkan pembelajaran tentang definisi dari materi yang dipelajari, tidak mendapatkan pembelajaran tentang 
DOI: https://doi.org/10.24127/ajpm.v9i3.2917

hubungan sebab akibat, dan tidak mendapatkan pembelajaran yang mempertimbangkan berbagai kemungkinan. Jadi diperoleh bahwa kesalahan konsep yang dialami oleh siswa maupun mahasiswa dipengaruhi oleh pembelajaran di kelas.

Salah satu upaya untuk mengatasi kesalahan konsep yang disebabkan oleh pembelajaran di kelas adalah dengan mengembangkan suatu model pembelajaran yang bertujuan untuk meningkatkan pemahaman konsep. Salah satu model pembelajaran yang dikembangkan oleh Setiawan dan Mustangin (2020a) untuk meningkatkan pemahaman konsep adalah model pembelajaran IDEA (Issue, Discussion, Establish, and Apply). Model pembelajaran IDEA ini merupakan rencana atau pola yang digunakan untuk merancang materi pembelajaran dan untuk membimbing pembelajaran di kelas yang berbasis pada empat kegiatan, yaitu: (1) Issue, yaitu kegiatan pembelajaran untuk memunculkan ideide saat menyelesaikan masalah sederhana, (2) Discussion, yaitu kegiatan mendiskusikan ide-ide yang digunakan untuk menyelesaikan masalah sederhana, sehingga ditemukan ide sebagai awal terbentuknya konsep, (3) Establish, yaitu menetapkan suatu konsep dari ide yang ditemukan, dan (4) Apply, yaitu menerapkan konsep yang telah ditetapkan untuk menyelesaikan masalah matematika atau masalah sehari-hari yang berkaitan dengan konsep yang sedang dipelajari.

Penelitian sebelumnya yang dilakukan oleh Setiawan dan Mustangin (2020b) adalah melakukan uji validitas model pembelajaran IDEA. Hasil uji validitas menunjukkan bahwa model pembelajaran IDEA ini valid, yaitu sesuai dengan syarat model pembelajaran yang baik, mampu meningkatkan pemahaman konsep dengan berorientasi pada model pencapaian konsep, dan memuat indikator-indikator pemahaman konsep dalam setiap sintaksnya (Setiawan \& Mustangin, 2020b). Setelah dinyatakan valid oleh para ahli dan praktisi, maka dapat dilakukan uji coba lapangan. Untuk itu, sebagai kelanjutan dari penelitian sebelumnya yang dilakukan oleh Setiawan dan Mustangin (2020b), maka penelitian ini bertujuan untuk melakukan uji coba lapangan dari model pembelajaran IDEA. Uji coba lapangan ini bertujuan untuk mengetahui masukan-masukan pengguna dan tingkat kepraktisan model pembelajaran IDEA untuk dilaksanakan dalam pembelajaran matematika. Karena, meskipun suatu model pembelajaran valid, tetapi jika tidak dapat dilaksanakan dalam pembelajaran, maka model pembelajaran tidak praktis (Akker, Gravemeijer, McKenney, \& Nieveen, 2006). Perbedaan penelitian ini dengan penelitian sebelumnya (Setiawan \& Mustangin, 2020b) adalah jika penelitian sebelumnya melakukan uji validitas model pembelajaran IDEA dengan subjek penelitian yaitu dua ahli pendidikan matematika dan satu guru matematika di jenjang Sekolah Menengah Atas, sedangkan penelitian ini adalah melakukan uji kepraktisan terhadap model pembelajaran IDEA dengan sampel penelitian adalah mahasiswa program studi pendidikan matematika.

\section{METODE PENELITIAN}

Penelitian ini merupakan penelitian bagian dari pengembangan model pembelajaran IDEA (Issue, Discussion, Establish, and Apply). Prosedur penelitian pengembangan model pembelajaran IDEA ini terdiri dari lima tahap, yaitu: (1) tahap 
investigasi awal, (2) tahap desain, (3) tahap realisasi atau kostruksi, (4) tahap tes, evaluasi, dan revisi, dan (5) tahap diseminasi/implementasi. Penelitian pada tahap tes, evaluasi, dan revisi terdiri dari dua kegiatan, yaitu kegiatan validasi model pembelajaran IDEA oleh dua orang ahli dan satu praktisi dan kegiatan uji coba lapangan dari model pembelajaran IDEA. Kegiatan validasi model pembelajaran IDEA telah dilakukan oleh Setiawan dan Mustangin (2020b) yang menunjukkan bahwa model pembelajaran IDEA telah valid secara teori. Sebagai lanjutan dari penelitian tersebut, maka penelitian ini merupakan kegiatan uji coba lapangan dari model pembelajaran IDEA.

Kegiatan uji coba lapangan terdiri dari dua tahap, yaitu uji coba kelompok kecil yang terdiri dari 5 mahasiswa dan uji coba kelompok besar yang terdiri dari satu kelas. Uji coba ini dilaksanakan di Universitas Islam Malang pada mahasiswa jurusan pendidikan matematika semester satu dengan mata kuliah Trigonometri tahun akademik 2019-2020. Uji coba kelompok kecil ini bertujuan mendapatkan masukan terhadap keterlaksanaan model pembelajaran IDEA sebelum diimplementasikan ke kelompok besar. Kelima mahasiswa tersebut dipilih berdasarkan kemampuan yang heterogen. Hal ini dikarenakan agar model pembelajaran IDEA yang akan diimplementasikan dapat dipahami oleh mahasiswa yang memiliki kemampuan rendah, sedang, dan tinggi.

Kegiatan uji coba kelompok kecil dilakukan dengan memberi Lembar Kerja Mahasiswa (LKM) yang telah disusun berdasarkan model pembelajaran IDEA kepada 5 mahasiswa untuk diselesaikan dengan menggunakan sintaks model pembelajaran IDEA yang terdiri dari 4 tahap, yaitu tahap menemukan ide (issue), tahap diskusi (discussion), tahap menetapkan konsep (establish), dan tahap menerapkan konsep (apply). Setelah mereka menyelesaikan LKM, maka kelima mahasiswa diberi angket untuk memberikan masukan-masukan terhadap pelaksanaan model pembelajaran IDEA. Selanjutnya masukan-masukan tersebut digunakan untuk merevisi LKM dan kegiatan pada sintaks model pembelajaran IDEA. Setelah LKM dan kegiatan pada sintaks model pembelajaran IDEA direvisi, maka dilakukan kegiatan uji coba kelompok besar.

Kegiatan uji coba kelompok besar ini dilakukan dalam satu kelas pada mata kuliah trigonometri yang terdiri dari 32 mahasiswa pendidikan matematika semester satu. Kegiatan uji coba kelompok besar ini dilakukan dalam tiga kali pertemuan. Pada pertemuan pertama dan kedua dilakukan pembelajaran dengan menggunakan model pembelajaran IDEA. Pada pertemuan ketiga mahasiswa diberi angket kepraktisan model pembelajaran IDEA. Pengisian angket kepraktisan ini bertujuan untuk mengetahui tingkat kepraktisan model pembelajaran IDEA dalam pembelajaran matematika. Angket kepraktisan ini secara umum terdiri dari 5 bagian, yaitu: (1) pelaksanaan kegiatan memunculkan ide-ide, (2) pelaksanaan kegiatan diskusi, (3) pelaksanaan kegiatan menetapkan konsep, (4) pelaksanaan kegiatan menerapkan konsep, dan (5) pelaksanaan model pembelajaran IDEA secara umum. Masing-masing pernyataan dalam angket menggunakan pilihan: tidak setuju (TS), kurang setuju (KS), setuju (S), dan sangat setuju (SS). Masing-masing diberi skor 1, 2, 3, 4 . Terdapat 23 item pernyataan yang harus 
DOI: https://doi.org/10.24127/ajpm.v9i3.2917

diisi oleh 32 mahasiswa. Diperoleh skor minimum adalah $1 \times 23 \times 32=736$ dan skor maksimum adalah $4 \times 23 \times$ $32=2.944$.

Dari skor minimum dan maksimum akan ditentukan kategori kepraktisan model pembelajaran IDEA untuk dilaksanakan dalam rangka meningkatkan pemahaman konsep dengan menggunakan interval rendah, sedang, tinggi, dan sangat tinggi.
Penentuan interval tersebut menggunakan kuartil, yaitu di bawah kuartil 1 rendah, di bawah kuartil 2 sedang, di bawah kuartil 3 tinggi, dan di atas kuartil 3 sangat tinggi. Dari interval tersebut diperoleh kategori kepraktisan model pembelajaran IDEA untuk digunakan dalam pembelajaran matematika yang dapat dilihat dalam Tabel 1.

Tabel 1. Kategori kepraktisan model pembelajaran IDEA.

\begin{tabular}{ccl}
\hline Skor & Kategori Kepraktisan & \multicolumn{1}{c}{ Keterangan } \\
\hline $736-1.288$ & Rendah & Model pembelajaran tidak praktis \\
$1.289-1.840$ & Sedang & Model pembelajaran kurang praktis \\
$1.841-2.392$ & Tinggi & Model pembelajaran praktis \\
$2.393-2.944$ & Sangat tinggi & Model pembelajaran sangat praktis \\
\hline
\end{tabular}

Batas kategori kepraktisan model pembelajaran IDEA ini adalah pada kategori tinggi. Jika skor hasil pengisian angket kepraktisan oleh mahasiswa berada di kategori tinggi atau sangat tinggi, maka model pembelajaran IDEA ini dapat diterapkan secara praktis dalam pembelajaran matematika untuk meningkatkan pemahaman konsep. Tetapi jika skor hasil pengisian angket berada pada kategori sedang atau rendah, maka model pembelajaran IDEA ini tidak dapat diterapkan secara praktis dalam pembelajaran matematika. selanjutnya dari kategori yang diperoleh akan diinterpretasikan secara kualitatif untuk menjelaskan makna dari hasil uji coba kelompok besar.

\section{HASIL DAN PEMBAHASAN}

Hasil penelitian ini terdiri dari dua tahap, yaitu hasil uji coba kelompok kecil dan hasil uji coba kelompok besar. Masing-masing dari hasil uji coba kelompok kecil dan kelompok besar dijelaskan berikut ini.

\section{Hasil Uji Coba Kelompok Kecil}

Tahap pertama adalah kegiatan uji coba kelompok kecil dari model pembelajaran IDEA yang dilakukan terhadap 5 mahasiswa program studi pendidikan matematika. Tujuan uji coba kelompok kecil ini adalah untuk mendapatkan masukan dari lima mahasiswa terhadap keterlaksanaan model pembelajaran IDEA. Masukanmasukan dari kelima mahasiswa terhadap keterlaksanaan dari masingmasing sintaks model pembelajaran IDEA dapat dilihat dalam Tabel 2.

Masukan-masukan dari hasil uji coba kelompok kecil dalam Tabel 2 digunakan untuk merevisi LKM dan menambahkan kegiatan-kegiatan pada sintaks model pembelajaran IDEA. Berdasarkan masukan-masukan yang tercantum dalam Tabel 2, maka LKM yang berhasil dibuat direvisi pada tahap memunculkan ide-ide (Issue), yaitu dengan ditambahkan petunjuk pengisian LKM dan menambahkan sedikit materi yang telah dipelajari oleh mahasiswa pada pertemuan sebelumnya. Kegiatan pada tahap diskusi (discussion) juga 
DOI: https://doi.org/10.24127/ajpm.v9i3.2917

ditambah dengan melakukan pembentukan kelompok secara heterogen dan dosen memberikan kesempatan kepada mahasiswa untuk melakukan tanya jawab tentang permasalahan mahasiswa dalam menyelesaikan masalah. Kegiatan pada tahap menetapkan (establish) ditambah dengan dosen memberi kesimpulan dan pemantapan dari materi yang dipelajari.
Serta kegiatan pada tahap menerapkan (apply) ditambah contoh soal. Hasil revisi LKM dapat dilihat dalam Gambar 1. Setelah LKM direvisi dan kegiatan pada tahapan pembelajaran ditambah sesuai masukan dari hasil uji kelompok kecil, maka model pembelajaran IDEA diterapkan pada uji coba kelompok besar.

Tabel 2. Masukan-masukan dari hasil uji coba kelompok kecil

\begin{tabular}{|c|c|c|}
\hline No. & Sintaks Model IDEA & Masukan-Masukan \\
\hline 1 & $\begin{array}{l}\text { Issue, yaitu tahap } \\
\text { memunculkan ide-ide. }\end{array}$ & $\begin{array}{l}\text { Melakukan review kembali materi sebelumnya dengan } \\
\text { menambah sedikit materi sebelumnya pada LKM untuk } \\
\text { mengetahui maksud dari masalah yang akan diselesaikan. } \\
\text { Diberi petunjuk untuk mengisi LKM agar mahasiswa } \\
\text { tidak kebingungan dalam mengerjakan LKM. }\end{array}$ \\
\hline 2 & $\begin{array}{l}\text { Discussion, yaitu tahap } \\
\text { mendiskusikan ide-ide } \\
\text { yang muncul. }\end{array}$ & $\begin{array}{l}\text { Dosen lebih perhatian ke mahasiswa. Lebih banyak tanya } \\
\text { jawab dalam membahas materi atau masalah antara dosen } \\
\text { dan mahasiswa. Terjadi diskusi antara dosen dan } \\
\text { mahasiswa dalam memecahkan masalah. Pembentukan } \\
\text { kelompok secara heterogen dari sisi kemampuan. }\end{array}$ \\
\hline 3 & $\begin{array}{l}\text { Establish, yaitu tahap } \\
\text { menetapkan ide yang } \\
\text { akan dibentuk konsep. }\end{array}$ & $\begin{array}{l}\text { Seteleh pembelajaran, dosen atau guru memberi } \\
\text { kesimpulan dengan dijelaskan kembali oleh dosen. } \\
\text { Melakukan pemantapan materi oleh dosen. }\end{array}$ \\
\hline 4 & $\begin{array}{l}\text { Apply, yaitu } \\
\text { menerapkan konsep. }\end{array}$ & $\begin{array}{l}\text { Diberikan contoh soal agar mempermudah dalam } \\
\text { menerapkan pengetahuan yang diperoleh. }\end{array}$ \\
\hline
\end{tabular}

\section{Hasil Uji Coba Kelompok Besar}

Tahap kedua adalah melakukan uji coba kelompok besar. Uji coba kelompok besar ini dilakukan terhadap 32 mahasiswa semester 1 pendidikan matematika pada mata kuliah Trigonometri. Uji coba ini dilaksanakan dalam tiga kali pertemuan. Pertemuan pertama, terlihat bahwa mahasiswa masih kesulitan dalam menerapkan model pembelajaran IDEA. Kesulitan mahasiswa disebabkan karena belum terbiasa dengan model pembelajaran IDEA. Kesulitan hampir terjadi pada setiap tahap dari model pembelajaran IDEA ini. Kesulitan pada tahap memunculkan ide (issue), yaitu mahasiswa sulit untuk menemukan ideide dan mencatat ide-ide yang digunakan untuk menyelesaikan masalah, hal ini dikarenakan mahasiswa pada jenjang sebelumnya hanya mendapatkan materi dari penjelasan guru dan tidak menggunakan pemikirannya sendiri untuk memahami suatu materi. Pada tahap diskusi (discussion) adalah juga terlihat bahwa mahasiswa kebingungan untuk mendiskusikan ide-ide mereka dengan teman-temannya. Hal ini dikarenakan mahasiswa jarang melakukan kegiatan belajar kelompok dengan mendiskusikan ide-ide mereka dan mahasiswa kesulitan untuk menuliskan ide-ide mereka. Pada tahap penetapan konsep (establish) juga terlihat kesulitan mahasiswa adalah mendefinisikan suatu konsep atau mendefinisikan suatu cara yang digunakan untuk menyelesaikan masalah. Hal ini disebabkan mahasiswa 
DOI: https://doi.org/10.24127/ajpm.v9i3.2917

tidak memahami cara menetapkan suatu konsep. Pada tahap penerapan konsep (apply) diketahui bahwa mahasiswa masih kesulitan dalam menyelesaikan masalah, karena mahasiswa belum memahami tentang konsep yang ditetapkan sebelumnya. Jadi pada pertemuan pertama ini diketahui bahwa model pembelajaran IDEA tidak berjalan dengan baik, karena mahasiswa

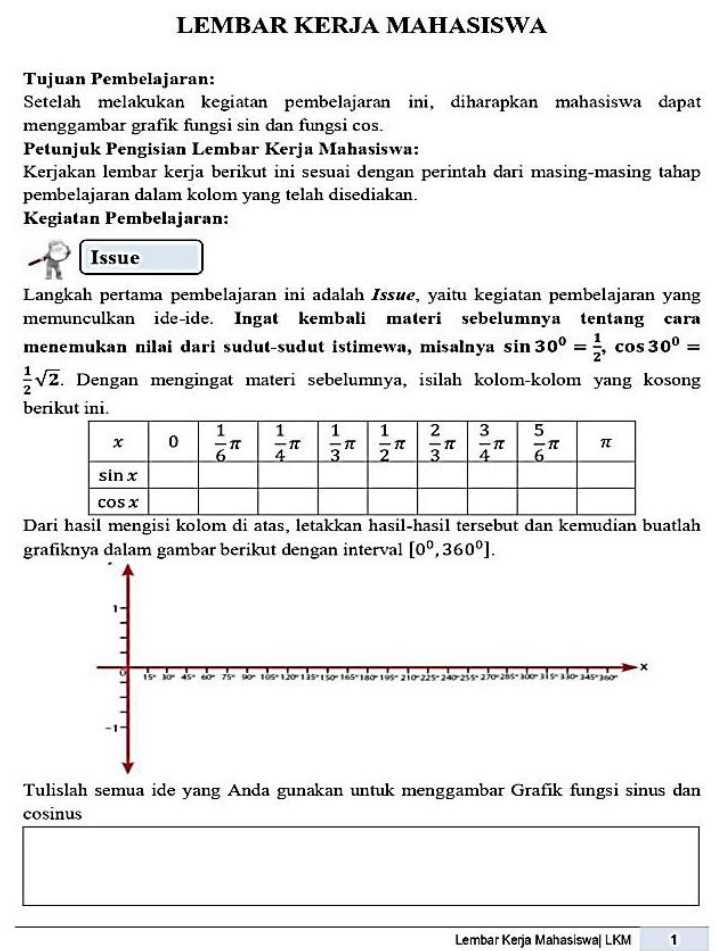

masih kesulitan dalam menerapkannya. Oleh karena itu, lembar kerja mahasiswa yang telah disusun kemudian direvisi terlebih dahulu sebelum pertemuan kedua untuk mencapai tujuan dari penelitian. Hasil revisi dari lembar kerja mahasiswa dapat dilihat pada Gambar 1 dan Gambar 2.

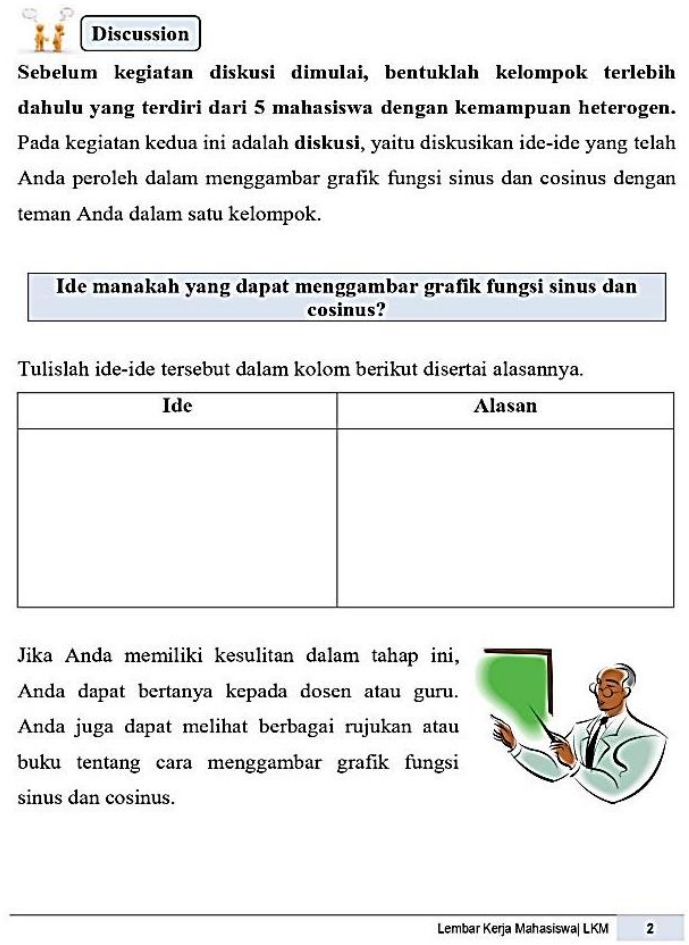

Gambar 1. Revisi lembar kerja mahasiswa pada bagian Issue dan Discussion

Pada pertemuan kedua terdapat sedikit kemajuan dalam menggunakan model pembelajaran IDEA setelah lembar kerja mahasiswa direvisi. Kemajuan pada pertemuan kedua yaitu pada tahap memunculkan ide (issue), mahasiswa sudah dapat menemukan dan menuliskan ide-ide yang mereka gunakan untuk menyelesaikan masalah. Hal ini dikarenakan mahasiswa memiliki keberanian untuk mengutarakan ide-ide mereka dalam belajar.
Pada tahap diskusi (discussion) sudah mulai terlihat bahwa mahasiswa sudah dapat saling bertukar ide yang mereka gunakan untuk menyelesaikan masalah, di mana mahasiswa sudah mampu menemukan ide-ide sederhana untuk menyelesaikan masalah. Pada tahap menetapkan konsep (establish) sudah terlihat bahwa mahasiswa sudah mampu menemukan ide sederhana yang mereka gunakan dalam menyelesaikan masalah, tetapi mahasiswa masih sedikit kebingungan untuk membuat definisi dari konsep yang mereka pelajari. Pada 
DOI: https://doi.org/10.24127/ajpm.v9i3.2917

tahap menerapkan (apply) dari konsep yang ditetapkan terlihat bahwa sebagian mahasiswa masih kesulitan untuk menyelesaikan masalah.

Kemajuan pada pertemuan kedua ini dikarenakan dua hal, yaitu: (1) dosen harus membimbing mahasiswa dalam setiap tahap dari model pembelajaran IDEA ini dalam rangka untuk memudahkan dan membiasakan mahasiswa dengan model pembelajaran yang baru, dan (2) setelah pertemuan pertama, mahasiswa diminta untuk

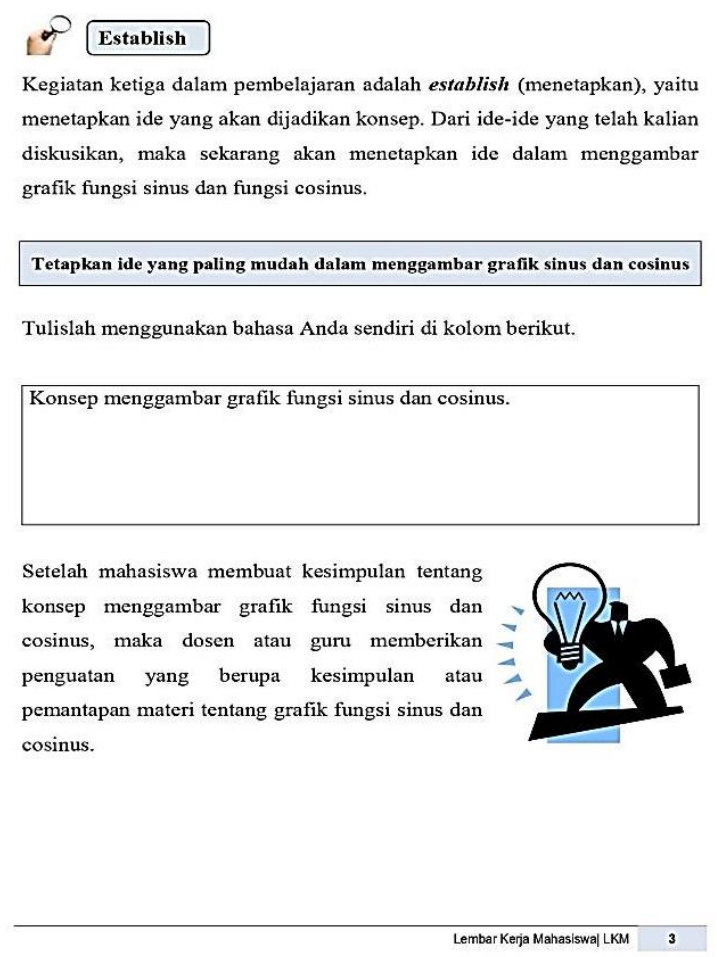

menyelesaikan LKM di rumah sebagai tugas mandiri dan mempelajari tahap demi tahap dari model pembelajaran IDEA ini. Hal ini sangat berpegnaruh karena ketika pertemuan pertama, mahasiswa belum tahu apapaun terkait dengan model pembelajaran IDEA kemudian di pertemuan kedua, mahasiswa sudah memiliki kesempatan lebih lama untuk mempelajari, memahami, dan membiasakan diri untuk belajar dengan menggunakan model IDEA.

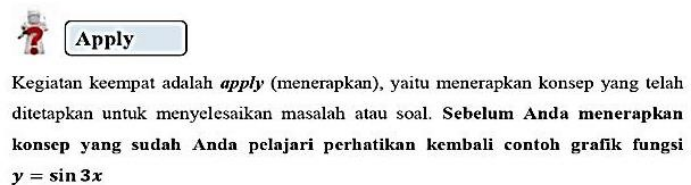
$y=\sin 3 x$

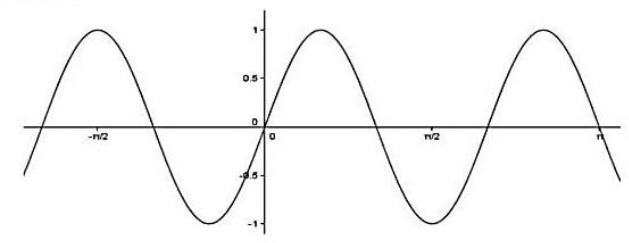

Gambarlah grafik fungsi

1. $y=\sin 2 x$ dan $y=2 \sin x$ dalam interval $\left[0^{\circ}, 360^{\circ}\right]$.

2. $y=\cos 2 x$ dan $y=2 \cos x$ dalam interval $\left[0^{\circ}, 360^{\circ}\right]$

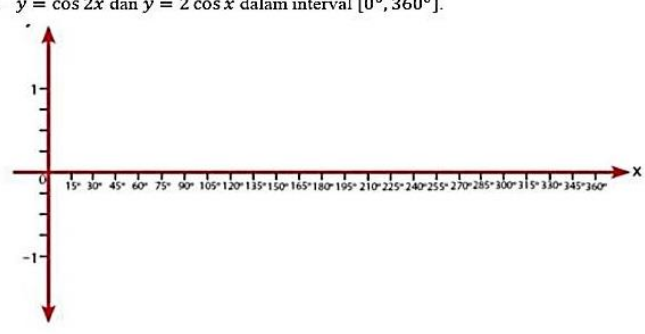

SEMOGA SUKSES!:

Gambar 2. Revisi lembar kerja mahasiswa pada bagian Establish dan Apply.

Pada pertemuan ketiga sudah tampak bahwa model pembelajaran IDEA ini dapat berjalan dengan baik. Mahasiswa sudah mengetahui proses pembelajaran dengan menggunakan model pembelajaran IDEA ini. Setelah pertemuan ketiga selesai, mahasiswa diminta untuk mengisi angket kepraktisan model pembelajaran IDEA untuk dilaksanakan dalam pembelajaran matematika. Diperoleh hasil angket yang diisi oleh 32 mahasiswa dapat dilihat dalam Tabel 3.

Dari Tabel 3 dapat diketahui bahwa total skor dari hasil perolehan pengisian angket kepraktisan model pembelajaran IDEA untuk diterapkan dalam pembelajaran matematika adalah 2.163. Dari skor ini diperoleh persentase kepraktisan model pembelajaran IDEA yaitu $\frac{2.163}{2.944} \times 100 \%=73,47 \%$. Ini artinya model pembelajaran 
DOI: https://doi.org/10.24127/ajpm.v9i3.2917

IDEA berada pada kategori tinggi dari kategori kepraktisan model pembelajaran IDEA (Tabel 1).

Tabel 3. Skor pengisian angket kepraktisan model pembelajaran IDEA.

\begin{tabular}{|c|c|}
\hline Pernyataan & Skor \\
\hline \multicolumn{2}{|l|}{ Pelaksanaan kegiatan memunculkan ide-ide (Issue) } \\
\hline 1. Pada awal pembelajaran, saya tertarik untuk mempelajari materi lebih lanjut. & \\
\hline 2. Topik yang diberikan memunculkan berbagai ide saya. & 85 \\
\hline 3. Masalah atau materi awal adalah sederhana. & 102 \\
\hline 4. Materi yang diberikan memiliki hubungan dengan materi sebelumnya. & 110 \\
\hline \multicolumn{2}{|l|}{ Pelaksanaan kegiatan diskusi (Discussion) } \\
\hline 5. Saya dapat bekerja dengan kelompok saya dengan baik. & \\
\hline 6. Saya dapat bertukar ide dengan teman sekelompok saya. & 100 \\
\hline 7. Saya dapat memilih ide sederhana dari berbagai ide. & \\
\hline 8. Saya senang dengan adanya diskusi dengan teman-teman. & 105 \\
\hline \multicolumn{2}{|l|}{ Pelaksanaan kegiatan menetapkan konsep (Establish) } \\
\hline 9. Saya dapat menemukan konsep dari ide. & \\
\hline $\begin{array}{l}\text { 10. Saya dapat menggunakan bahasa sendiri untuk mendefinisikan ide yang } \\
\text { menjadi konsep. }\end{array}$ & 96 \\
\hline $\begin{array}{l}\text { 11. Saya dapat meninjau kembali konsep yang telah saya temukan dengan konsep } \\
\text { yang telah ada. }\end{array}$ & 8 \\
\hline \multicolumn{2}{|l|}{ Pelaksanaan kegiatan menerapkan konsep (Apply) } \\
\hline nyelesaikan soal latihan. & \\
\hline 13. Saya dapat memberikan contoh dan non contoh. & \\
\hline \multicolumn{2}{|l|}{ Pelaksanaan model pembelajaran IDEA secara umum } \\
\hline 14. Pada awal kegiatan pembelajaran, pembelajaran menarik perhatian saya. & 97 \\
\hline $\begin{array}{l}\text { 15. Sejak awal pembelajaran, saya termotivasi untuk mengetahui lebih jauh } \\
\text { tentang materi pembelajaran. }\end{array}$ & \\
\hline ipahami dengan jelas. & \\
\hline 17. Setelah $n$ & 10 \\
\hline $\begin{array}{l}\text { 18. Dosen sering memberikan bantuan kepada mahasiswa jika mengalami } \\
\text { kesulitan dalam belajar. }\end{array}$ & \\
\hline 19. Waktu & \\
\hline 20. Saya ingin 1 & 10 \\
\hline 21. Setelah pembelajaran ini, saya jadi ingin tahu lebih jauh tentang materi. & \\
\hline $\begin{array}{l}\text { 22. Pada saat pembelajaran, saya berusaha keras untuk menguasai materi dengan } \\
\text { baik. }\end{array}$ & 10 \\
\hline 23. Di akhir pembelajaran, Dosen memandu mahasiswa menarik kesimpulan & \\
\hline
\end{tabular}

Berdasarkan Tabel 3 dapat dilihat bahwa hal-hal yang membuat model pembelajaran IDEA ini memiliki tingkat kepraktisan yang tinggi yaitu: (1) Pada tahap memunculkan ide-ide harus memberikan masalah sederhana dan materi yang diberikan memiliki hubungan dengan materi sebelumnya. (2) Pada tahap diskusi harus membuat mahasiswa senang dalam pembelajaran dan dapat bertukar ide dengan teman dalam satu kelompok. (3) Pada tahap menetapkan konsep harus dapat membuat mahasiswa menggunakan bahasa sendiri untuk mendefinisikan ide yang menjadi konsep. (4) Pada tahap menerapkan konsep harus dapat membuat mahasiswa dapat 
menyelesaikan soal latihan dan dapat memberikan contoh dan bukan contoh. Jadi secara umum dapat dikatakan bahwa setiap tahapan model pembelajaran IDEA dapat diterapkan dalam pembelajaran matematika. Secara sederhana dapat dikatakan bahwa model pembelajaran IDEA ini praktis untuk dilaksanakan dalam pembelajaran matematika yang bertujuan untuk meningkatkan pemahaman konsep.

Kemudian mahasiswa diminta untuk memberikan komentar-komentar terhadap pelaksanaan model pembelajaran IDEA ini. Komentarkomentar beberapa mahasiswa antara lain: (1) Pengadaan LKM membuat pembelajaran lebih baik, karena bisa berdiskusi dan memahami materi secara mendalam, (2) Pada awalnya saya merasa kesulitan dalam memahami materi, lama kelamaan saya tertarik untuk memahami materi yang diajarkan dan suasana belajar sangat menyenangkan, karena tidak hanya mendengarkan, tetapi saya melakukan diskusi kelompok dan presentasi, (3) Pada awal pembelajaran saya masih kesulitan dengan apa yang dimaksud model pembelajaran yang digunakan. Tetapi setelah mengerjakan soal dan memulai diskusi, saya merasa memahami apa yang dipelajari, (4) Pembelajaran dilakukan dengan cukup menarik untuk dipelajari lebih lanjut oleh mahasiswa, tetapi terkadang saya kurang mengerti untuk memahami materi dan setelah saya mengerjakan contoh soal, saya lebih mengerti materi pelajaran, dan (5) Model pembelajaran ini mengasah kreativitas mahasiswa, cara berpikir mahasiswa dalam memahami dan menyelesaikan suatu materi dengan baik dan benar.

Dari hasil pengisian angket dan komentar mahasiswa mengenai model pembelajaran IDEA ini diperoleh kelebihan dan kekurangan model pembelajaran IDEA yang dapat dilihat dalam Tabel 4.

Tabel 4. Kelebihan dan kekurangan model pembelajaran IDEA.

\begin{tabular}{|c|c|}
\hline Kelebihan & Kekurangan \\
\hline 1. Meningkatkan pemahaman konsep. & 1. Membutuhkan waktu \\
\hline 2. Meningkatkan pemahaman materi yang dipelajari & yang relatif lama. \\
\hline melalui diskusi dan 1 & 2. Membutuhkan bimbingan \\
\hline 3. Membuat suasana belajar menyenangkan melalui & dari dosen atau guru saat \\
\hline 4. Meningkatkan minat mahasiswa dalam belajar. & model pembelajaran \\
\hline 5. Meningkatkan kreativitas mahasiswa. & IDEA. \\
\hline 6. Meningkatkan kemampuan berpikir ma & \\
\hline
\end{tabular}

Solusi dari kekurangan model pembelajaran IDEA ini adalah dengan memberikan sistem pendukung yang berupa LKM yang disusun berdasarkan model pembelajaran IDEA untuk diselesaikan di rumah. Dengan demikian masalah waktu yang relatif lama dapat diselesaikan.
Dari penelitian diperoleh hasil uji coba lapangan terbagi menjadi dua, yaitu hasil uji coba kelompok kecil dan hasil uji coba kelompok besar. Hasil uji coba kelompok kecil menunjukkan bahwa petunjuk dalam pengerjaan LKM dan materi yang telah dibahas pada pertemuan sebelumnya perlu di cantumkan dalam pembuatan lembar 
kerja mahasiswa maupun lembar kerja siswa, sehingga mahasiswa maupun siswa dapat menggunakan lembar kerja secara efektif. Hasil ini sesuai dengan hasil penelitian Nasution dan Sinaga (2017) yang menunjukkan bahwa kriteria efektif dari lembar kerja siswa adalah siswa dapat dan aktif dalam menggunakan LKS. Selain itu LKS maupun LKM juga harus memberi kemudahan kepada siswa, mahasiswa, guru, dan dosen dalam proses belajar mengajar. Tetapi pada penelitian ini tidak membahas mengenai desain LKM maupun LKS, untuk itu penelitian lanjutan dapat melakukan pengembangan LKM atau LKS berdasarkan model pembelajaran IDEA yang efektif. LKM maupun LKS dalam penelitian ini digunakan sebagai penunjang untuk mengetahui tingkat kepraktisan model pembelajaran IDEA.

Selanjutnya hasil uji coba kelompok besar yang menjadi fokus penelitian. Hasil uji coba kelompok besar menunjukkan bahwa tingkat kepraktisan model pembelajaran IDEA adalah sebesar $73,47 \%$ atau berada pada kategori tinggi (lihat Tabel 1). Ini artinya model pembelajaran IDEA praktis untuk dilaksanakan dalam pembelajaran matematika dengan tujuan meningkatkan pemahaman konsep. Lebih lanjut Akker, Gravemeijer, McKenney, dan Nieveen (2006) mengatakan bahwa ada tiga aspek kelayakan yang harus dibedakan dalam membuat desain pembelajaran, yaitu: kepraktisan, relevansi, dan keberlanjutan. Sedangkan penelitian Usman, Saud, dan Achmad (2018) dan Setiani, Sanjaya, dan Jatmiko (2019) mengacu pada tiga aspek, yaitu validitas, kepraktisan, dan efektivitas. Jadi ada lima hal yang penting untuk ditentukan dalam pengembangan model pembelajaran, yaitu: relevansi, kepraktisan, validitas, efektivitas, dan keberlanjutan.

Penelitian ini fokus pada kepraktisan model pembelajaran IDEA. Kriteria kepraktisan dari suatu model pembelajaran harus mampu menjawab pertanyaan apakah desain ini dapat digunakan secara realistis dalam praktik sehari-hari? dan bagaimana waktu, tenaga, dan biaya dalam menggunakan desain tersebut? (Akker, Gravemeijer, McKenney, \& Nieveen, 2006). Karena jika suatu desain terbukti valid, tetapi tidak dapat dijalankan dalam praktiknya karena terlalu mahal dan memakan waktu, maka desain tersebut tidak praktis. Kriteria kepraktisan dari suatu desain pembelajaran juga ditentukan berdasarkan tujuan untuk melakukan desain pembelajaran (Akker, Gravemeijer, McKenney, \& Nieveen, 2006). Tujuan pengembangan model pembelajaran IDEA ini adalah untuk meningkatkan pemahaman konsep. Jadi model pembelajaran IDEA ini telah memenuhi kriteria kepraktisan dari suatu model pembelajaran, yaitu: (1) model pembelajaran IDEA dapat digunakan dalam praktik pembelajaran matematika, (2) waktu, tenaga, dan biaya dalam menggunakan model pembelajaran IDEA ini terjangkau, dan (3) sintaks model pembelajaran IDEA ini telah sesuai dengan tujuan model pembelajaran ini, yaitu untuk meningkatkan pemahaman konsep.

\section{KESIMPULAN DAN SARAN}

Hasil penelitian menunjukkan bahwa persentase kepraktisan model pembelajaran IDEA sebesar $73,47 \%$. Ini berarti bahwa model pembelajaran praktis untuk dilaksanakan dalam pembelajaran matematika dengan tujuan meningkatkan pemahaman konsep. Penelitian selanjutnya adalah melakukan uji kepraktisan model 
pembelajaran IDEA di jenjang sekolah dasar dan sekolah menengah. Selain itu, penelitian yang dapat dilakukan selanjutnya adalah melakukan uji efektivitas model pembelajaran IDEA dalam meningkatkan pemahaman konsep.

\section{DAFTAR PUSTAKA}

Afifah, D. S. N., Nafi'an, M. I., \& Putri, M. I. (2018). Analisis Kesalahan Mahasiswa Dalam Menyelesaikan Soal Kalkulus Peubah Banyak. MaPan: Jurnal Matematika Dan Pembelajaran, 6(2), 207-220. https://doi.org/10.24252/mapan.20 $18 \mathrm{v} 6 \mathrm{n} 2 \mathrm{a} 7$

Afriadi, J. (2019). Identifikasi Kesalahan dan Miskonsepsi Mahasiswa Calon Guru Matematika Pada Topik SPLDV. Math Educa Journal, 2(2), 231243. https://doi.org/10.15548/mej .v2i2.191

Akker, J. Van den, Gravemeijer, K., McKenney, S., \& Nieveen, N. (2006). Educational Design Research. London and New York: Routledge Taylor \& Francis Group.

Arvianto, I. R. (2017). Kesalahan Mahasiswa Dalam Menyelesaikan Soal Integral Berdasarkan Gaya Kognitif. Jurnal Matematika Dan Pendidikan Matematika, 2(1), 3647.

Farhan, M., \& Zulkarnain, I. (2019). Analisis Kesalahan Mahasiswa pada Mata Kuliah Kalkulus Peubah Banyak Berdasarkan Newmann' s Error Analysis. Jurnal Kajian Pendidikan Matematika, 4(2), 121-134.

Jana, P. (2018). Analisis Kesalahan Mahasiswa Dalam Menyelesaikan
Soal Matematika Pada Pokok Bahasan Vektor. Jurnal Mercumatika: Jurnal Penelitian Matematika Dan Pendidikan Matematika, 2(2), 8 . https://doi.org/10.26486/jm.v2i2.3 98

Lembang, S. T., \& Ba'ru, Y. (2018). Analisis Kesalahan Mahasiswa dalam Menyelesaikan Soal Aljabar Linier Pada Materi Sistem Persamaan Linier. Jurnal KIP, 6(3), 249-256.

Lusiana, R. (2017). Analisis Kesalahan Mahasiswa Dalam Memecahkan Masalah Pada Materi Himpunan Ditinjau Dari Gaya Kognitif. Jurnal Penelitian Dan Pembelajaran Matematika, 10(1), 24-29. https://doi.org/10.30870/ jppm.v10i1.1290

Nasution, T. K., \& Sinaga, B. (2017). Development of Student Worksheet Geometry Based Metacognitive Strategy Through Creative Thinking Ability. IOSR Journal of Research \& Method in Education (IOSR-JRME), 7(4), 1018. https://doi.org/10.9790/73880704041018

Oktaviana, D. (2018). Analisis Tipe Kesalahan Berdasarkan Teori Newman Dalam Menyelesaikan Soal Cerita Pada Mata Kuliah Matematika Diskrit. Edu Sains: Jurnal Pendidikan Sains \& Matematika, 5(2), 22. https://doi.org/10.23971/eds.v5i2.7 19

Rosmaiyadi. (2018). Analisis Kesalahan Penyelesaian Soal Aljabar pada Mahasiswa Program Studi Pendidikan Matematika STKIP Singkawang. Journal Pendidikan Matematika, 12(1), 59-70. 
Sembiring, R. K. B. (2017). Analisis Kesalahan Mahasiswa dalam Mata Kuliah Analisis Kompleks. Juril AMIK MBP, 5(2), 60-68.

Setiani, R., Sanjaya, I. G. M., \& Jatmiko, B. (2019). ARICESA as an alternative learning model to improve learning motivation and understanding of student concepts. International Journal of Instruction, 12(2), 383-398. https://doi.org/10.29333/iji.2019.1 $2225 \mathrm{a}$

Setiawan, Y. E. (2015). Analisis Domain dan Dampak Mathematical Knowledge for Teaching Terhadap Pengajaran. In Hobri (Ed.), Reformasi Pendidikan dalam Memasuki ASEAN Economic Community (AEC) (pp. 1263-1271). Jember: FKIP Universitas Jember.

Setiawan, Y. E. (2019). Peta Konsep dalam Pembelajaran Matematika. Lumajang: AL-Mukmin Yes.

Setiawan, Y. E. (2020a). Analisis Kemampuan Siswa dalam Pembuktian Kesebangunan Dua Segitiga. Al-Khwarizmi: Jurnal Pendidikan Matematika Dan Ilmu Pengetahuan Alam, 8(1), 23-38. https://doi.org/http://dx.doi.org/10. 24256/jpmipa.v8i1.80

Setiawan, Y. E. (2020b). Analisis Kesalahan Siswa dalam Menilai Kebenaran Suatu Pernyataan. Jurnal Didaktik Matematika, 7(1), 13-31. https://doi.org/10.24815/ jdm.v7i1.14495

Setiawan, Y. E. (2020c). The Thinking Process of Students Using Trial and Error Strategies in Generalizing Linear Patterns. Numerical: Jurnal Matematika Dan Pendidikan Matematika, 4(1),
1-12. https://doi.org/https://doi. org/10.25217/numerical.v4i1.839

Setiawan, Y. E., \& Mustangin. (2020a). Panduan Model Pembelajaran IDEA (Issue, Discussion, Establish, and Apply). Lumajang: CV. Al-Mukmin Yes.

Setiawan, Y. E., \& Mustangin. (2020b). Validitas Model Pembelajaran IDEA ( Issue, Discussion, Establish, and Apply) untuk Meningkatkan Pemahaman Konsep. Jurnal Penelitian Pendidikan Dan Pengajaran Matematika, 6(1), 53-60.

Setiawan, Y. E., Purwanto, Parta, I. N., \& Sisworo. (2020). Generalization Strategy of Linear Patterns From Field-Dependent Cognitive Style. Journal on Mathematics Education, 11(1), 77-94. https://doi.org/http://doi.org/10.223 42/jme.11.1.9134.77-94

Setiawan, Y. E., \& Syaifuddin. (2020). Peningkatan Kompetensi Profesionalitas Guru Melalui Pelatihan Desain Pembelajaran Peta Konsep. Jurnal Pengabdian Kepada Masyarakat, 26(3), 148153. https://doi.org/http://dx.doi. org/10.24114/jpkm.v26i3.16377

Usman, M., Saud, S., \& Achmad, A. K. (2018). Learning Model Development of Teams-GamesTournaments (TGT) In Learning German Vocabulary (Wortschatz) for Senior High School Students in Makassar. International Journal of Language Education, 2(2), 105112. https://doi.org/10.26858/ ijole.v2i 2.5828 